\title{
The New European Union Whistleblowing Directive: In Comparison to Indonesia's Practice
}

\author{
József Hajdú ${ }^{1}$, Rofi Aulia Rahman ${ }^{2}$ \\ 1 Department of Labour Law and Social Security, University of Szeged, Hungary. Email: hajdu@juris.u- \\ szeged.hu \\ 2 Faculty of Law, Universitas Surabaya, Indonesia. Email: rofiauliarahman@staff.ubaya.ac.id
}

\begin{abstract}
With the European Union Whistleblowing Directive (2019), the topic of whistleblowing is becoming increasingly important for EU MS's public and private entities. Whistle-blowers might play a vital role in exposing corruption, fraud and mismanagement of the EU's supranational norms. The Directive introduced minimum standards for the protection of whistle-blowers and obliges many public and private entities to introduce their own internal whistleblowing channels. The EU also can take some lessons from Indonesia about the practice and obstacle in implementing whistleblowing system. The aim of this article is to introduce the new EU Whistleblowing Directive's main features and some presumable obstacles for implementation. The hypothesis is that the new Directive might enhance the fairwork-place environment, roll back fraud and corruption, reduce work-related wrongdoing and manage equal treatment and nodiscrimination policy including bullying and sexual harassment. However, some theoretical and pragmatic discrepancies will be introduced as well.
\end{abstract}

Keywords: European Union; Whistleblowing; Legal Protection; Scope of the Directive; Whistleblowing System

\section{Introduction}

With the European Union (hereinafter: EU) Whistleblowing Directive, ${ }^{1}$ the topic of whistleblowing is becoming increasingly important for EU MS's public and private entities. Whistleblowers might play a vital role in exposing corruption, fraud and mismanagement. Because many whistleblowers face reprisals after they report, adequate legal protection is needed urgently. Many countries in Europe have failed to implement this. Therefore, in order to guarantee an EU-wide standard for the protection of whistleblowers, the EU adopted a Directive for whistleblower protection in December 2019. It introduced minimum standards for the protection of whistleblowers and obliges many public and private entities to introduce their own internal whistleblowing channels. In a two-year implementation period, EU Member States are obliged to implement the Directive into their own national laws basically until $2021 .^{2}$

\footnotetext{
1 Directive (EU) 2019/1937 of the European Parliament and of the Council of 23 October 2019 on the Protection of persons who report breaches of Union Law.

2 EU Whistleblowing Directive (2020), https://www.business-keeper.com/en/eu-whistleblowing-directive (accessed 14.01-2021)
} 
The recent EU Whistleblower Directive symbolizes a new wave of thought around the topic. ${ }^{3}$ At the European level, the most important legal forerunners of the Directive came from the Council of Europe (COE) and the European Court of Human Rights (ECtHR). ${ }^{4}$ The CoE adopted a number of Resolutions and reports calling on its State Parties to protect whistleblowers ${ }^{5}$ and the ECtHR decided ${ }^{6}$ in favour of whistleblowers in several decisions on the basis of protection for freedom of expression. ${ }^{7}$

The aim of this article is to introduce the new EU Whistleblowing Directive's main features and some presumable obstacles for implementation. The optmistic hypothesis is that the new Directive might enhance the fairwork-place environment, roll back fraud and corruption, reduce work-related wrongdoing and manage equal treatment and nodiscrimination policy including bullying and sexual harassment. ${ }^{8}$

\section{The Notion of Whistleblowing}

The directive contains some definitions, but the definition of whistleblowing is missing. Therefore, it might be useful to share some elements of it. Literally, it can be referred to as "blowing the whistle", like the referees of many sports games. Within the discussed scope, whistleblowing is when an individual reports wrongdoing in an organisation, for example, financial misconduct or discrimination. This person is often an employee but can also be a third party such as a supplier or customer. However, it can easily be illegal if the exposed information threatens the company's economic interests (rights) or national security.

Basically, there are two main channels of whistleblowing: 1. internal and 2. external. 1. Internal whistleblowing is when someone makes a report within his/her own organisation. Often companies implement whistleblowing channels for this purpose so that employees and other stakeholders can speak up if they become aware of misconduct. 2. External whistleblowing is when a person blows the whistle publicly, either to the media, police or via social media channels. People often opt to blow the whistle publicly if they have little faith in their organisation's investigation or reporting

\footnotetext{
3 Matt Kelly (2020) The EU Whistleblowing Directive: Finding the Right Solution, https://www.ganintegrity.com/blog/eu-whistleblower-directive/ (accessed 14.06.2021)

4 Protecting whistleblowers (2020) https://www.coe.int/en/web/cdcj/activities/protecting-whistleblowers (accessed 12.07.2021)

${ }^{5}$ See P. Omtzigt, 'The Protection of Whistle-Blowers', Parliamentary Assembly, Committee on Legal Affairs and Human Rights, Report, Doc. 12006, 14 September 2009. See also Council of Europe, Congress of Local and Regional Authorities 36th Session, The Protection of Whistleblowers: Challenges and Opportunities for Local and Regional Government. Report CG36 (2019)14final, 3 April 2019; Resolution 444 (2019), Debated and adopted by the Congress on 3 April 2019, second sitting.

${ }^{6}$ See Guja v Moldova, no 1085/10 (no 2), 27 February 2018, a case following a decade after Mr Guja had been vindicated by the ECtHR, Guja v Moldova, no 14277/04, 12 February 2008. Other relevant cases of the ECtHR on protection of whistleblowers are Marchenko v Ukraine, no 4063/04, 19 February 2009; ECtHR, Kudeshkina $v$ Russia, no 29492/05, 26 February 2009; ECtHR, Heinisch v Germany, no 28274/08, 21 July 2011; ECtHR, Sosinowska v Poland, no 10247/09, 18 October 2011, ECtHR, Bucur and Toma v Romania, no 40238/02, 8 January 2013, ECtHR, Matúz v Hungary, no 73571/10, 21 October 2014; ECtHR, Pasko v Russia, no 69519/01, 22 October 2009.

7 Vigjilenca Abazi: The European Union Whistleblower Directive: A 'Game Changer' for Whistleblowing Protection? Industrial Law Journal, Volume 49, Issue 4 (December 2020): 640-656.

8 Moritz Homann (2020) What is Whistleblowing: FAQ for Companies https://www.eqs.com/complianceblog/whistleblowing-faq-companies/ (accessed 10.07.2021)
} 
procedure, have tried speaking up internally with no result or if there is no whistleblowing system in place.

It is important to underline that there is an important distinction between whistleblowing and raising a workplace grievance. A grievance is a matter of personal interest (individual complaint) and does not impact on the wider public, whereas a whistleblowing report usually relates to more widespread concerns as outlined above.

\section{The Main Issues of the Directive}

\subsection{Protection of whistleblowers}

From the very beginning of the history of whistleblowing it is one of the most important considerations. Whether an employee chooses to speak up when they see wrongdoing is a personal decision. Many whistleblowers are motivated by wanting to do the right thing. However, even though employers are prohibited from seeking revenge after an employee has exposed wrongdoing, a whistleblower's career may still suffer. Whistleblowers often stand alone and friends they thought they could trust in their workplace might turn their back on them in order to protect their own reputation. Even if an anonymous whistleblowing system is in place, whistleblowers still need courage and determination to expose wrongdoing, potentially exposing colleagues or the organisation they have worked for over many years. ${ }^{9}$

Many EU Member States - before the Directive - only had partial legal protections in place for whistleblowers. Change has taken place in Europe with the EU Whistleblowing Directive, which contains broad free speech protections for whistleblowers in both the public and the private sectors in all Member States of the EU. ${ }^{10}$

The purpose of the Directive is to enhance the enforcement of EU law and policies in specific areas by laying down common minimum standards providing for a high level of protection of persons reporting breaches of Union law. The Directive imposes an obligation to protect whistleblowers against any retaliation, or threatened or attempted retaliation measures. Retaliation includes but is not limited to dismissal, demotion, withholding promotion, transfer of duties, change of place of work, reduced wages, changes in working hours, withholding training, negative performance reviews and disciplinary measures. ${ }^{11}$

The essential points of the protection are: 1 . Protection not only exists for employees who report their concerns, but also for job applicants, former employees, supporters of the whistleblower and journalists. 2. These persons are protected from dismissal, degradation and other discrimination. 3. Protection applies only to reports of wrongdoing relating to EU law, but the EU is encouraging national legislators to extend this to also covering wrongdoing relating to national laws). 4. The whistleblower can initially choose whether to report a concern internally within the company or directly to the competent

\footnotetext{
${ }^{9}$ Martin Jefflen (2019) Be prepared for transposition; https://www.eurocadres.eu/news/new-best-practice-guideon-whistleblowing-for-trade-unions/ (accessed 28. 07. 2021)

10 Moritz Homann (2020) What is Whistleblowing: FAQ for Companies, loc.cit

11 Vigjilenca Abazi, loc.cit
} 
supervisory authority. If nothing happens in response to such a report, or if the whistleblower has reason to believe that it is in the public interest, they can also go directly to the public. They are protected in both cases. With these safeguards, the EU is signaling to whistleblowers that they have nothing to fear while encouraging individuals to report on company infringements. ${ }^{12}$

However, the whistleblower is only protected from those reprisals if the whistleblower had reasonable grounds to assume that the relevant information was true and correct and that the reporting related to breaches (of EU supranational legislation) that fell within the scope of the Directive at the time of the reporting. On this basis, if a whistleblower is exposed to such reprisals after making a report (covered by the scope of the Directive), it will be assumed that the reprisals are initiated due to the report and the employer must, in this case, prove that the reprisals were not initiated due to report. This will be a heavy burden of proof to lift by the employer, and expectedly it will be rather similar to the protection currently found in the EU based anti-discrimination and equal treatment legislation. ${ }^{13}$

In court or other official proceedings relating to a whistleblowing disclosure, the burden of proof is reversed. This means that if a whistleblower demonstrates that they reported a breach or made a public disclosure and suffered a negative consequence, there will be a presumption that the negative consequence was an act of reprisal. It will be up to the person who took the measure with a negative consequence (i.e. the employer) to demonstrate that it was justified and was not taken in retaliation for the whistleblowing disclosure. ${ }^{14}$

In turn, this places a number of legal obligations on organisations, with the adoption of safe reporting channels (such as whistleblower websites and hotlines) chief among them. The Directive is explicit in specifying that such channels should be: "designed, established and operated in a secure manner that ensures that the confidentiality of the identity of the reporting person and any third party mentioned in the report is protected, and prevents access thereto by non-authorised staff members". 15

In addition, the Member States may add more procedural rules when implementing the Directive. ${ }^{16}$ In practice, the national whistleblower protection laws in EU Member States will handle anonymous reporting in different ways. For example, countries such as Germany and France focus more on shielding the identity of the whistleblower through data protection laws, although even then the laws allow for some circumstances when a whistleblower's identity might be revealed (such as when an accused person demands to know where an allegation came from). ${ }^{17}$

12 Moritz Homann (2020) EU (2020) Whistleblowing Directive - All You Need to Know Right Now, loc.cit

13 Pia Skovgaard Hansen, et.al., (2020) An overview and analysis of the new whistleblower directive; https://www.twobirds.com/en/news/articles/2020/global/an-overview-and-analysis-of-the-new-whistleblowerdirective (accessed 09.08.2021)

14 Vigjilenca Abazi, loc.cit

15 Eurocadres (2020), New best practice guide on whistleblowing for trade unions, available at https://www.eurocadres.eu/news/new-best-practice-guide-on-whistleblowing-for-trade-unions/ (accessed 06.08.2021)

16 Pia Skovgaard Hansen, et al., loc.cit

17 Janina Mackiewicz (2020) EU Whistleblowing Meter Launched to Monitor Transposition of EU Directive on Whistleblowing; https://whistleblowerprotection.eu/ (accessed 12.08.2021) 


\subsection{The scope of the Directive}

The Directive sets out common standards for protecting individuals who report information on breaches of EU law they acquired in a 'work-related context'. It protects whistleblowers in both the public and private sectors and covers not only workers, but also job applicants, former employees, shareholders, board members, trainees and the self-employed. Family members, and colleagues of whistleblowers and legal entities connected to them are also protected. ${ }^{18}$

The Directive impacts hundreds of thousands of organisations and small and mediumsized enterprises (SMEs) right across Europe that employ more than 50 people. But it is those with 250 employees ${ }^{19}$ or more that will be required to comply first. ${ }^{20}$

The EU Whistleblower Directive provides protections for designated violations of EU law. ${ }^{21}$ However, EU Member States may choose to extend the material scope of the Directive. One of the interesting things to follow will be to what extent Member States may choose to include reporting on breaches of other sets of legislation under the implementation legislation. Obvious elements to consider would be workplace harassment and discrimination along with various types of misuse of governmental/ public funds, including e.g. bribery, which are not directly covered by the Directive. ${ }^{22}$ However, it must be underlined that the Directive explicitly excludes political whistleblowing. ${ }^{23}$

\subsection{Reporting channels}

The directive does not impose multiple reporting forms or state that submission must be done orally or in writing, providing multiple reporting channels will broaden access to invite external parties, such as suppliers and customers, to bring their allegations to the involved entities' attention, an initiative that is strongly encouraged by the Directive. Furthermore, in order to be in compliance with the Directive, organizations will need to identify a technology partner to provide whistleblower and case management services. ${ }^{24}$

The whistleblower can choose to report an incident internally first within the company or directly to the relevant supervisory authority. If nothing is done in response to such a report or if the whistleblower has reason to believe that there is a public interest, they

\footnotetext{
18 Vigjilenca Abazi, loc.cit

19 For companies in the private sector with 50 to 249 employees it is noted that there is a "special deadline" for implementation in Article 26 (2), according to which Member States may decide to implement the rules for (and thus oblige) companies with between 50 and 249 employees no later than by 17 December 2023 (i.e. two years later than the "main" implementation deadline). On this basis, Member States have more time to introduce rules for whistleblowing channels for companies with between 50 and 249 employees. The legal position is therefore considered more favorable for these companies if the Member States postpone the implementation on this basis.

20 Karin Henriksson: EU Whistleblower Directive: 2021 deadline looms for thousands of companies https://www.lexology.com/library/detail.aspx?g=f114a693-a3f9-4c31-9363-6e45c77bb4b9 (accessed 09.08.2021)

${ }^{21}$ Violation of EU law in the following areas is covered: 1. public procurement, 2. financial services, 3. money laundering prevention, 4. product security and product identity, 5 . environmental protection, 6 . consumer and data protection, 7. public health, 8 . radiation security and nuclear security and, 9. protection of the privacy.

${ }_{22}^{2}$ Matt Kelly, loc.cit

${ }^{23}$ It refers to the disclosure of information protected by an official secrets regime.

${ }^{24}$ Matt Kelly, loc.cit
} 
can also go directly to the public. ${ }^{25}$ There are three reporting channels indicated in the Directive: 1. internal reporting, 2. external reporting and 3. public disclosure.

\subsubsection{Internal reporting}

The internal reporting must comply with requirements relating to security, confidentiality and impartiality. There are also procedural requirements in the Directive relating to notification, acknowledgement and follow-up of a whistleblowing disclosure. ${ }^{26}$ At a minimum, the Directive requires that internal reporting channels contain the following elements:

a. Internal channels and procedures for reporting which: a) Are secure and guarantee the confidentiality of the reporting party and any other mentioned third party. b) Allow for acknowledgment of receipt within 7 days. c) Have clear and easily accessible information on reporting to external authorities. d) Allow for reporting in writing and/or orally through telephone lines or other voice messaging services.

b. The ability to receive reports both from the organization's employees and other persons in contact with the entity in a work-related context. Such persons could be third parties, suppliers, partners, etc.

c. Companies with a headcount between 50 and 249 employees may share resources for the receipt and possibly the investigation of reports.

d. Recordkeeping in line with confidentiality requirements for an appropriate timeframe, either as a stored audio recording or in the form of detailed minutes signed by the reporting person.

The introduction of the Directive is a major opportunity for companies to push for a strong ethical culture that will prevent misconduct, but also encourages employees to use internal channels in order to build trust. ${ }^{27}$

\subsubsection{External reporting}

Member States must establish independent and autonomous external reporting channels for receiving and handling reports. These must comply with broadly the same requirements as internal reporting channels. ${ }^{28}$ External reporting should be used when internal whistleblowing channels are compromised or could not reasonably be expected to work properly.

\footnotetext{
${ }^{25}$ Moritz Homann (2020) What is Whistleblowing: FAQ for Companies, loc.cit

26 Vigjilenca Abazi, loc.cit

27 Chris Terwisscha Van Scheltinga (2019) EU Whistleblower Directive: An Impetus for A Strong Corporate Ethics Culture; available at https://www.ganintegrity.com/blog/eu-whistleblower-directive-impetus-strong-corporate-ethicsculture/ (accessed 05.12.2021)

28 Vigjilenca Abazi, loc.cit
} 
The authorities must have dedicated staff members who must be trained to provide the public with information on whistleblower reporting procedures and receive and follow up on the reports, as well as asking the reporting person for further information where necessary. ${ }^{29}$

\subsubsection{Public Disclosures}

A whistleblower who decides to disclose a concern to the public (for example, by informing the media) is protected under the Directive if either: they firstly reported internally or externally but no timely action was taken, or they had reasonable grounds to believe that the breach constituted an imminent or manifest danger for the public interest, or in the case of external reporting, this channel would be insufficient as there is a low prospect of the breach being effectively addressed, or that there would be a risk of retaliation due to particular circumstances of the case. ${ }^{30}$

The above-mentioned provisions do not apply to cases where a person directly discloses information to the press pursuant to specific national provisions establishing a system of protection relating to freedom of expression and information.

\subsection{Guarantee provisions of the whistleblower's reports}

There are some guarantee provisions which are applied for both internal and external reporting processes.

A) Confidentiality. According to the Directive, it is up to the relevant Member State to define how to establish the necessary whistleblower channels as long as the relevant potential whistleblowers' identities are ensured to be kept confidential. The MS must ensure that some minimum requirements in the Directive are followed, e.g. that: 1 . The channel is designed, established and operated in a secure manner that ensures the confidentiality of the reporting person's identity and that any third party mentioned in the reporting is protected, and that prevents unauthorised employees' access to it. 2. A confirmation of receipt of the report is given to the reporting person within seven days. 3. An impartial, competent person or department is appointed to follow up on the reports. This person or department must maintain communication with the reporting person and, where necessary, request further information from and provide feedback to this reporting person. 4. A careful follow-up is carried out on the designated person or department. 5. A reasonable time limit is set for giving feedback which does not exceed three months from the acknowledgment of receipt or, if no acknowledgment was sent to the reporting person, three months from the expiry of a period of seven days after the alert was given. 6 . The channel contains clear and easily accessible information on the procedures for making reports externally to competent authorities.

\footnotetext{
${ }^{29}$ Guide to EU Directive on Whistleblower Protection; https://tenders.guru/publications/whistleblower-protection (accessed 05.08.2021)

$30 \mathrm{ibid}$
} 
B) Anonymity. According to the Directive's Preamble 34, it is up to each Member State to decide $^{31}$ whether it should be possible to report anonymously or not and, in this connection, whether each Member State is obliged to follow up on anonymous reports. ${ }^{32}$

C) Personal data protection. The management of whistleblowing cases requires an appropriate corporate culture which reflects the organization's intention to handle personal data and whistleblowing reports confidentially and with the utmost security. Whistleblowers will feel more secure knowing their data is protected and under stricter regulation. ${ }^{33}$

Moreover, this issue can get complicated quickly because while whistleblower protection laws vary from one EU state to another, the EU General Data Protection Regulation (GDPR) applies universally across the entire Union. So the subject of a complaint might have privacy rights that apply under the GDPR, even as a company tries to protect the identity of a whistleblower under other laws. This complexity can have implications for how the company handles the intake of complaints, investigations, and even follow-up communication with the original reporter. ${ }^{34}$

D) Penalties. Under the Directive, Member States have an obligation to implement effective, proportionate and dissuasive penalties on individuals and legal entities that: a) hinder or attempt to hinder whistleblowing; b) retaliate against anyone protected in the Directive; c) bring legal proceedings against anyone protected in the Directive; d) breach the duty to keep the identity of whistleblowers confidential. In addition, anyone who knowingly discloses or publicly reports false information is also subject to these penalties and organisations affected must be able to bring damages actions in relation to false disclosures under national law. ${ }^{35}$

\section{Some Theoretical Discrepancies}

According to the basic EU principle of supranationality, workers in Europe will encounter whistleblower protection laws at multiple levels. The specific requirements of each country's whistleblower protection rules can vary quite a bit. Hence, organizations working across Europe face compliance with multiple whistleblower protection laws simultaneously. ${ }^{36}$ There are some theoretical discrepancies to mention here.

First, the EU Whistleblowing Directive obliges all Member States of the EU to adopt their own version of the Directive as national law (implementation) by the end of $2021 .{ }^{37}$ For

\footnotetext{
31 If one or more Member States decide to only follow up on non-anonymous reports, it may cause doubt on whether employees (or external partners) at the end of the day are willing to report any breaches of EU law even though the employees (or external partners) will be protected from reprisals.

32 Pia Skovgaard Hansen, et al., loc.cit

33 European Data Protection Supervisor: Whistleblowing https://edps.europa.eu/data-protection/dataprotection/reference-library/whistleblowing en (accessed 14.07.2021)

${ }^{34}$ ibid

35 Vigjilenca Abazi, loc.cit

${ }^{36}$ Martin Jefflen (2019) Be prepared for transposition; available at https://www.eurocadres.eu/news/new-bestpractice-guide-on-whistleblowing-for-trade-unions/ (accessed 28. 07. 2021)

${ }^{37}$ Today, only 10 out of 27 Member States in the EU have comprehensive whistleblower legislation in place. Even for the Member States that have comprehensive legislation in place, there may be significant differences between the current legislation and the new directive.
} 
example, a problematic minimum standard issue is that the Directive itself says companies working in the EU that have 50 or more employees must create internal reporting systems to help employees and other third parties report violations of EU law and to protect those persons from retaliation when they do speak up. ${ }^{38}$ At a minimum, the national laws must include all the whistleblower protections listed in the EU Directive, although they can also go further and include more protections if a country wants to. For example, the EU Directive lets individual states decide how to handle anonymous reporting, or whether to give financial rewards to whistleblowers who bring concerns to the government that result in monetary penalties.

Second, there are national whistleblower protection laws in each EU Member State. Some countries have already adopted whistleblower protection laws that reflect the EU Directive's goals, others have embedded the same protections in anti-corruption laws. For example: 1. France: The Sapin II Act of 2016, foremost a corporate anti-corruption law, also defines whistleblowers and the protections they must receive. 2. Ireland: The Protected Disclosures Act of 2014. 3. Italy: Law No. 179/2017, known as "the Whistleblowing Law," adopted in 2017. and Hungary: Act CLXV of 2013 on Complaints and Public Interest Disclosure.

However, not every EU Member State has specific whistleblower protection statutes yet. Germany only has whistleblower protections that arise from general employment law and labour agreements. Spain has whistleblower protections for the securities industry, and its criminal code encourages businesses to protect whistleblowers, but that is all. ${ }^{39}$

Third, according to the Directive, any company with 50 employees or more is required to establish a robust internal reporting and investigations system that will allow employees and anyone working on behalf of the company to submit allegations of misconduct as well as strong controls to prevent retaliation against whistleblowers. The problematic issue is that the reports need to be handled with diligence and impartially and companies must allocate adequate competence to investigations.

Fourth, mandatory arbitration and NDAs stifling whistleblowers The introduction of legal protection for whistleblowers bypassing internal reporting channels is clearly a strong argument for a focus on developing internal ethics culture. However, this development does not stand alone; other questionable practices that stifle reporting of misconduct have come under fire recently. ${ }^{40}$

a) Mandatory arbitration clauses: a widely used means of alternative dispute resolution. It is common in the corporate world to include mandatory arbitration clauses in employment contracts. This means the employee's claims regarding harassment, discrimination, and other related topics may not be fought in court but have to be settled in private arbitration.

The practice has come under fire in recent years for the perceived imbalance of power in such proceedings as there is typically no option to appeal, the amount and type of evidence that may be supplied are severely limited, and there is no (sympathetic) jury to

\footnotetext{
${ }^{38}$ Matt Kelly (2020), loc.cit

${ }^{39}$ Matt Kelly (2020), ibid

40 ibid
} 
hear the claims. Moreover, the proceedings stay private, meaning that allegations of serious misconduct, including by senior leadership, stay hidden from the public. As a result, employees are far less likely to win cases in private arbitration and when they do, the awards tend to be far lower than in employment-based litigation.

b) Another practice that is subject to heavy criticism at the moment is the use of nondisclosure agreements (NDAs) struck between employers and whistleblowers that attempt to raise concerns internally. ${ }^{41}$ The EU whistleblower Directive contains a provision requiring states to ensure that the rights and remedies provided for in the Directive may not be waived or limited by any type of agreement, including a pre-dispute arbitration agreement. ${ }^{42}$

Fifth, whistleblowers throughout the European Union are set to enjoy wide-ranging protections from retaliation when they report their concerns, regardless of whether the concerns were raised internally or not. In practice this means that whistleblowers can no longer be stifled using non-disclosure agreements, forced arbitration, or other questionable practices that have long been commonplace in the corporate world.

The Directive must be transposed individually by each Member State by December 2021. Each local version of legislation is likely to differ in detail but should reflect the Directive's overriding aim: to ensure a baseline level of protection for whistleblowers across the EU. However, as seen in the lead-up to the EU's General Data Protection Regulation (GDPR) in 2018, widespread awareness of the law amongst those that need to comply is likely to remain relatively low until transposition is completed. ${ }^{43}$

\section{Indonesian Whistleblowing System}

\subsection{Regulation of Whistlewblowing}

In Indonesia, whistleblower protections are primarily for criminal cases. The Witness and Victim Protection Law is the primary piece of whistleblower legislation. Companies frequently enquire, however, whether the Indonesian Employment Law contains any whistleblowing provisions. Furthermore, in Witness and Victim Protection Law, anyone who reports, witnesses, and is being a victim of a criminal case, they have a right to be protected by the state. The reason the government enacted that law is to ensure the justice and to protect the vulnerable group (victim and witness) who are possibly under pressure due to the position and condition because of the criminal action they knew. ${ }^{44}$ The state, to protect the victim and witness, established a new state auxiliary organ (Indonesia's Witness and Victim Protection Agency (LPSK)) has a function to protect victim and witness.

Besides having Witness and Victim Protection Law, Indonesia has Employment Law, yet that law does not regulate explicitly on whistleblowing. However, two provisions of the

\footnotetext{
${ }^{41} \mathrm{~A}$ lot of criticism has been directed at the treatment of Howard Wilkinson, the former head of Danske Bank's Baltics trading unit, who blew the whistle on what is suspected money-laundering said amount to over EUR 200 billion.

${ }^{42}$ Chris Terwisscha Van Scheltinga, loc.cit

${ }^{43}$ Karin Henriksson, loc.cit

${ }^{44}$ Nabila Azzahra, Rugun Romaida Hutabarat, Urgensi Perlindungan Hukum Terhadap Whistleblower dalam Upaya Pemberantasan Tindak Pidana Korupsi di Indonesia, Jurnal Hukum Adigama, Vol.4 No.1 (2021): 1293
} 
Employment Law (Law Number 13 of 2013) provide certain protections for employees who are aware of their employer's criminal acts. Article 153(1)(h) states that an employer cannot terminate an employee for reason that the employee reports to the relevant authority an alleged criminal offense by the employer. Article 169 paragraphs (1) and (2) in essence states that an employee may terminate the employment relationship and still be entitled to severance, service and compensation pay if the employer, among other things, incites and/or orders the employee to commit an act contrary to laws and regulations. Consequently, if an employee's employment relationship is terminated for the aforementioned reason, the employee is entitled to two times severance pay, once service pay, and once compensation pay. In comparison, an employee who resigns on his or her own volition is only entitled to compensation pay.

Furthermore, Indonesia has a Consumer Financial Protection Act 2010. That act contains provisions protecting whistleblowers. Section 1057 of the CFPA 2010 protects employees of organizations that provide financial products or services to consumers from retaliation for disclosing information, testifying or assisting in any investigation relating to a violation of this Act, or objecting to or refusing to participate in any activity that is deemed to be a violation of this Act. Whistleblower protection is available if the whistleblower provides information or assistance in an investigation to his or her employer, the Consumer Financial Protection Bureau, or any other state, local, or federal government authority or law enforcement. Any employee who is discharged or faces retaliation as a result of a violation of S.1057 may file a complaint with the labor secretary within 180 days of the violation occurring.

In sum up, Indonesia does not have a special act to regulate whistleblowing system and sometimes called as justice collaborator specifically yet the whistleblowing regime is returned to each institution and legal entities. ${ }^{45}$

\subsection{Practice and Obstacle}

The practice of whistleblowing system in Indonesia has been developing in Indonesia since 1999 through the enactment of Law Number 31 of 1999 on Corruption Eradication. After the rolling-coaster years, Indonesia has more effort to strengthen and protect the role of whistleblower by enacting some regulations, such as employment act, consumer financial protection act, and one of the most important legal breakthrough is the establishment of witness and victim protection agency under the law number 31 of 2014. Even Indonesia has some regulations on whistleblowing system, nevertheless, the internal case, fraud, corruption, still exist and hard to decrease the number of those cases. ${ }^{46}$ The problem was because the whistleblower unintended to spread the information since they were under pressure by the higher position of their company. The witness and victim law 2014 also applies for a half-protection for the whistleblower as stated in Article 10 Paragraph (2) that in the event that there is a lawsuit against a Witness, Victim, Witness Perpetrator and/or Reporting Party for the testimony and/or

\footnotetext{
45 See Lilik Mulyadi, Perlindungan Hukum Whistleblower dan Justice Collaborator dalam Upaya Penanggulangan Organized Crime di Indonesia, Padjajaram Jurnal IImu Hukum 1, No.3 ((2014): 579

${ }^{46}$ Benjamin S. Raharjo, A Comparative Analysis of Whistleblower's Protection in Indonesia and United States of America, Jurnal Humaniora 8, No.2 (2017): 182
} 
report that will be, is being, or has been given, the lawsuit must be postponed until the case that he reports or gives testimony has been decided by the court and obtain permanent legal force. The law is not fully covering the position of whistleblower, while it has an important information to reveal justice and case being scrutinized. ${ }^{47}$

Nonetheless, the whistleblower system in Indonesia has some impediments to implementation. According to Article 5 of the Witness and Victim Law, one of the more difficult rights to satisfy is the right to a new identity ${ }^{48}$ and anonymity. ${ }^{49}$ The mainstream media's attention is one of the variables that contribute to society digging for witness and victim information. As a result of their intense scrutiny, the LPSK is unable to deal with the witness and victim in secret. As a result, following the disclosure of his or her identity, the whistleblower frequently experiences terror when testifying about the incident. The other instance is PT Sarinah, which was successfully referred to the Public Attorney for corruption by a whistleblower. Unfortunately, the director handed the whistleblower the letter of report which was obtained from the Public Attorney, which resulted in the whistleblower being sacked by the firm. ${ }^{50}$ This demonstrates that, while Indonesia has some legislation relating to whistleblowing, their enforcement are ineffective in protecting whistleblowers. The cause of the issue could be due to fragmented regulation and inconsistencies among the regulations, which renders law enforcement ineffective.

After the idea of the EU Directive is proposed and becoming an important issue, it is necessary to learn its implementation in several countries to ensure that no errors occur in practice and to be able to provide a clear mechanism for entities in implementing a whistleblowing system. Thus, in comparison to the practice in Indonesia, where it is still extremely difficult to implement an effective whistleblowing system due to a variety of factors such as scattered rules and lack of law enforcement. A whistleblowing system indeed is for reducing crime, wrongdoing, and mismanagement, if the system managed with improper treatment, otherwise, it will increase and exacerbate the issue of corruption, fraud, wrongdoing, and mismanagement.

\section{Conclusion}

The EU Whistleblower Directive is an important legal development but that it is only in the early stages towards meaningful protection, rather than a 'game changer' for

\footnotetext{
47 Ratna Juwita, Perlindungan Hukum Terhadap Whistleblower di Indonesia: Sinergi Antara United Nations Convention Against Corruption dan Hukum Nasional Tentang Perlindungan Saksi dan Korban, Justitia Et Pax 32, No.1 (2016): 103

48 The rights to get new identitiy is hard to be fulfilled because the culture of Indonesian is collectivist. When someone changed the identitiy, it means that, the relatives and colleague will lose them, see Firman Qusnulyakin, 2015, Pemberian Identitas Baru bagi Saksi dan Korban Sulit Dilakukan, available at https://www.beritasatu.com/nasional/267643/pemberian-identitas-baru-bagi-saksi-dan-korban-sulit-dilakukan accessed on December 2nd, 2021

49 See Frandyo Izzak Muskita, Effectiveness testing of reporting systems and organizational responses toward whistleblowing intentions, Journal of Contemporary Accounting, Vol.1 No.3, 2019, p.133

50 See Bambang Hari (2015), Kisah Sang Whistleblower dari PT Sarinah, https://kbr.id/saga/092015/kisah sang whistleblower dari_pt sarinah/75981.html (accessed on 7.12.2021). The leak of whistleblowber identitiy's case is Susno Duadji's case, he is a top rank of Police leaked the corruption case within his organization. Due to this case, he accussed for the libel of Police of Republic of Indonesia, and finally he was found guilty for the case he is handled. The key witness for Susno Duadji's case then found dead due to traffic accident
} 
whistleblowers in the EU. The new requirements of the EU Whistleblower Directive definitely raise the bar for companies' internal reporting programs, yet the underlying aim of the law is to adopt a proactive approach to whistleblowing and leverage the insights that flow into an investigations program. The fundamental aim of the new directive is to strengthen compliance with and enforcement of specific areas of EU law, by making it mandatory for all concerned companies and authorities to establish a whistleblower scheme, and by this to strengthen the protection of whistleblowers reporting EU law breaches within the scope of the directive. The next step for EU Member States now is to implement the Directive into national law until 17 December 2021. Private sector organisations with between 50 and 249 employees have time until 17 December 2023 to implement the obligation to establish reporting channels for whistleblowers.

\section{References}

Abazi, Vigjilenca. "The European Union Whistleblower Directive: A 'Game Changer'for Whistleblowing Protection?." Industrial Law Journal 49, no. 4 (2020): 640-656.

Bambang Hari (2015), Kisah Sang Whistleblower dari PT Sarinah, https://kbr.id/saga/092015/kisah sang whistleblower dari pt sarinah/75981.html (accessed on 7.12.2021)

Benjamin S. Raharjo, A Comparative Analysis of Whistleblower's Protection in Indonesia and United States of America, Jurnal Humaniora 8, No.2 (2017)

Bucur and Toma v Romania, no 40238/02, 8 January 2013

Chris Terwisscha Van Scheltinga (2019) EU Whistleblower Directive: An Impetus For A Strong Corporate Ethics Culture; https://www.ganintegrity.com/blog/euwhistleblower-directive-impetus-strong-corporate-ethics-culture/ (accessed 19. 07.2021)

Council of Europe, Congress of Local and Regional Authorities 36th Session, The Protection of Whistleblowers: Challenges and Opportunities for Local and Regional Government. Report CG36 (2019)14final, 3 April 2019; Resolution 444 (2019), Debated and adopted by the Congress on 3 April 2019, second sitting.

EU Whistleblowing Directive (2020), https://www.business-keeper.com/en/euwhistleblowing-directive (accessed 14.01-2021)

European Data Protection Supervisor: Whistleblowing https://edps.europa.eu/dataprotection/data-protection/reference-library/whistleblowing_en (accessed 14. 07.2021)

Firman Qusnulyakin, 2015, Pemberian Identitas Baru bagi Saksi dan Korban Sulit Dilakukan, available at https://www.beritasatu.com/nasional/267643/pemberianidentitas-baru-bagi-saksi-dan-korban-sulit-dilakukan accessed on December 2nd, 2021

Guide to EU Directive on Whistleblower Protection; https://tenders.guru/ publications/whistleblower-protection (accessed 05.08.2021) 
Guja v Moldova, no 1085/10 (no 2)

Heinisch v Germany, no 28274/08, 21 July 2011

Janina Mackiewicz (2020) EU Whistleblowing Meter Launched to Monitor Transposition of EU Directive on Whistleblowing; https://whistleblowerprotection.eu/ (accessed 12.08.2021)

Karin Henriksson (2020) EU Whistleblower Directive: 2021 deadline looms for thousands of companies https://www.lexology.com/library/detail.aspx?g=f114a693-a3f94c31-9363-6e45c77bb4b9, (accessed 09.07.2021)

Kudeshkina v Russia, no 29492/05, 26 February 2009

Lilik Mulyadi, Perlindungan Hukum Whistleblower dan Justice Collaborator dalam Upaya Penanggulangan Organized Crime di Indonesia, Padjajaram Jurnal IImu Hukum 1, No.3 (2014)

Marchenko v Ukraine, no 4063/04, 19 February 2009

Martin Jefflen (2019) Be prepared for transposition; https://www.eurocadres.eu/news/ new-best-practice-guide-on-whistleblowing-for-trade-unions/ (accessed 28. 07. 2021)

Matt Kelly (2020) The EU Whistleblowing Directive: Finding the Right Solution, https://www.ganintegrity.com/blog/eu-whistleblower-directive/ (accessed 14.06. 2021)

Matúz v Hungary, no 73571/10, 21 October 2014

Moritz Homan (2020) EU Whistleblowing Directive - All you need to know right now, available at https://www.eqs.com/compliance-blog/eu-whistleblower-protection/ (accessed 12. 01.2021)

Moritz Homan (2020) What is Whistleblowing: FAQ for Companies https://www.eqs.com/compliance-blog/whistleblowing-faq-companies/ (accessed 10.07.2021)

Muskita, Frandyo Izak, Intiyas Utami, and Aprina Nugrahesthy Sulistya Hapsari. "Effectiveness testing of reporting systems and organizational responses toward whistleblowing intentions." Journal of Contemporary Accounting 1, no. 3 (2019): 131-144.

Nabila Azzahra, Rugun Romaida Hutabarat, Urgensi Perlindungan Hukum Terhadap Whistleblower dalam Upaya Pemberantasan Tindak Pidana Korupsi di Indonesia, Jurnal Hukum Adigama, Vol.4 No.1 (2021): 1293

New best practice guide on whistleblowing for trade unions (2020) https://www.eurocadres.eu/news/new-best-practice-guide-on-whistleblowingfor-trade-unions/ (accessed 06.08.2021)

P. Omtzigt, 'The Protection of Whistle-Blowers', Parliamentary Assembly, Committee on Legal Affairs and Human Rights, Report, Doc. 12006, 14 September 2009.

Pasko v Russia, no 69519/01, 22 October 2009 
Pia Skovgaard Hansen, Mia Boesen, Søren Narv Pedersen (2020) An overview and analysis of the new whistleblower directive; https://www.twobirds.com/en/news/ articles/2020/global/an-overview-and-analysis-of-the-new-whistleblowerdirective (accessed 09.08.2021)

Protecting whistleblowers (2020) https://www.coe.int/en/web/cdcj/activities/ protecting-whistleblowers (accessed 12.07.2021)

Ratna Juwita, Perlindungan Hukum Terhadap Whistleblower di Indonesia: Sinergi Antara United Nations Convention Against Corruption dan Hukum Nasional Tentang Perlindungan Saksi dan Korban, Justitia Et Pax 32, No.1 (2016)

Sosinowska v Poland, no 10247/09, 18 October 2011

Šepec, Miha, Jan Stajnko, Klara Avsec, Tamara Dugar, Živa Šuta, and Suzana Žilič Fišer. "The European whistleblowing directive: a legislative barrier between journalists and their sources?" Media, Culture \& Society 42, no. 7-8 (2020): 1528-1544.

Whistleblowing, European Data Protection Supervisor; https://edps.europa.eu/dataprotection/data-protection/reference-library/whistleblowing_en (accessed 16.07. 2021)

Conflict of Interest Statement: The author(s) declares that the research was conducted in the absence of any commercial or financial relationship that could be construed as a potential conflict of interest.

Copyright: (C) HALREV. This is an open access article distributed under the terms of the Creative Commons Attribution 4.0 International License (CC-BY 4.0), which permits unrestricted use, distribution, and reproduction in any medium, provided the original author and source are credited.

Hasanuddin Law Review (Hasanuddin Law Rev. - HALREV) is an open access and peer-reviewed journal published by Faculty of Law, Hasanuddin University, Indonesia.

Open Access 